DOI https://doi.org/10.30525/978-9934-26-182-4-36

\title{
ВДОСКОНАЛЕННЯ ФІЗИЧНОЇ ПІДГОТОВЛЕНОСТІ СТУДЕНТІВ 3 ПОРУШЕННЯМ ПОСТАВИ
}

\author{
Городецька О. О. \\ кандидат наук з фізичного виховання та спорту, \\ викладач кафедри фізичного виховання \\ та лікувальної фізичної культури
}

Вінницький національний медичний університет імені М. І. Пирогова

Куц Б. О.

аспірант кафедри біології

Вінницький національний медичний університет імені М. І. Пирогова

\section{Романенко O. I.}

старший викладач кафедри фізичного виховання та лікувальної фізичної культури

Вінницький національний медичний університет імені М. І. Пирогова м. Вінниця, Україна

Порушення постави $\epsilon$ досить розповсюдженою вадою опорнорухового апарату та часто супроводжується погіршенням діяльності деяких систем організму, найчастіше серцево-судинної, дихальної та нервової. Розповсюдженість порушень постави у студентів зумовлена складністю організації роботи і відсутністю оптимальних методик корекції [6, с. 112].

Значна частина досліджень із проблем постави у студентів присвячена корекції постави, виявленню характеру порушень, розробці комплексів фізичних вправ, які сприяють попередженню можливих і виправленню наявних порушень. Разом із тим, проблема комплексного підходу до процесу формування постави 3 використанням різноманітних засобів фізичного виховання в умовах ЗВО залишається до кінця не вивченою. Недостатньо обгрунтовані методичні положення щодо використання фізичних вправ для розвитку фізичних якостей 3 метою раціонального впливу на поставу студентів.

Розроблені програми, які використовуються для студентів передбачають головним чином їх вплив на опорно-руховий апарат. Для вдосконалення фізичної та функціональної підготовленості студентів пропонують використовувати фізичні навантаження різного спрямування. 
Відсутній також єдиний підхід до регламентації фізичних навантажень, зокрема за їх інтенсивністю, періодичністю, оптимальними параметрами обсягу в залежності від віку та рівня функціональної підготовленості.

Основною метою фізичного виховання для студентів вищих навчальних закладів передбачає збереження і зміцнення здоров'я молоді. На жаль, існуюча у вищих навчальних закладах України система фізичного виховання не забезпечує сповна ефективного удосконалення фізичної i функціональної підготовленості студентської молоді. Незважаючи на такий стан в методиці проведення занять 3 фізичного виховання у вищих навчальних закладах за останні роки не відбулося суттєвих змін. Разом 3 тим, реалізація функціонального потенціалу студента повинна базуватися на науково обгрунтованих параметрах фізичних навантажень, що передбачає наявність не лише методичних основ розвитку фізичних здібностей, а й співвідношення фізичних навантажень різної спрямованості з урахуванням вікових особливостей [6, с. 111].

У даний час відбувається активний пошук нових методів і форм, які б сприяли підвищенню якості підготовки майбутніх спеціалістів. Однак, ситуація ускладнюється переходом на трансферну форму навчання, що припускає зменшення кількості годин, відведених на фізичне виховання, $\mathrm{i}$ переміщення їх у розряд самостійної роботи, що при несформованій мотивації до занять може проявитися в зниженні рухової активності студентів у цілому. Враховуючи скорочення годин, необхідно забезпечувати високу моторну щільність заняття, зважати на обсяг фізичних навантажень у режимі дня і навчальному тижні [4]. Наприклад, на заняттях 3 фізичного виховання, що проводяться на першій парі, доцільно використовувати навантаження малої (ЧСС в діапазоні 110-150 уд·хв ${ }^{-1}$ ) або середньої (ЧСС в діапазоні 130-150 уд ·хв ${ }^{-1}$ ) інтенсивності, що забезпечує високу працездатність протягом дня. У випадку, коли заняття проводиться на 3-4-й парі, ЧСС не повинна перевищувати 150-160 уд·хв .

Ж. А. Бєліковою [2, с. 19] доведено доцільність комплексного застосування гімнастичних вправ хатха-йоги, які включають статичні, динамічні, дихальні вправи для корекції деформації хребта й підвищення рівня функціональної тренованості студентів 3 функціональними порушеннями опорно-рухового апарату О. А. Мартинюк [7, с. 10] розроблено програму корекції порушень просторової організації тіла студенток у процесі фізичного виховання. У цю програму автор включила вправи силової спрямованості, які допомагають зміцненню та відновленню сили м'язів, що беруть участь у формуванні та підтримці ортоградної пози, кісткової системи, сполучної тканини (зв'язок, сухожиль); вправи, на розвиток гнучкості, які сприяють поліпшенню 
функціонального стану м'язової, сполучної та кісткової тканини; вправи аеробної спрямованості для підвищення й підтримку рівня функціональних можливостей серцево-судинної і дихальної систем.

М. В. Дудко [3, с. 33] обгрунтовано і розроблено технологію профілактики порушень біогеометричного профілю постави студентів. Розроблено зміст занять, що містить в собі використання фізичних вправ із систем пілатесу, стретчинга та атлетичної гімнастики.

Необхідно також відзначити одне 3 останніх фундаментальних досліджень, проведених А. І. Альошиною [1, с. 16]. Фахівцем обгрунтовано концепцію профілактики й корекції функціональних порушень ОРА в дітей та молоді, яка розроблена з урахуванням передумов виконання оздоровчої діяльності, концептуальних підходів, які покладені в основу мети, завдань, принципів та функцій, а також технології іiі реалізації та критеріїв ефективності.

За даними авторів [3, с. 32] необхідно використовувати метод активної корекції, який передбачає: застосування спільного тренування з метою оздоровлення та зміцнення фізичного розвитку дітей та підлітків; проведення спеціальної тренування опорно-рухового апарату і активізація функції дихання; збільшення рухливості в зоні викривлення; розвантаження хребта (розтягнення зв'язкового апарату і укорочених м'язів); принцип вигинання хребта в напрямку, протилежному викривлення, мобілізація його; вправи в балансуванні (рівновага в русі, рівномірне зміцнення м'язів тулуба і нижніх кінцівок); застосування симетричних i асиметричних вправ; розвиток механізму правильного дихання [3, с. 5].

Аналіз літературних джерел свідчить, що резервом підвищення ефективності занять $€$ забезпечення мотивації молоді до занять конкретної спрямованості. Як свідчить досвід та аналіз останніх досліджень, студенти, що навчаються в навчальних групах, створених за принципом спортивної спеціалізації, мають вищі показники фізичної та функціональної підготовленості порівняно зі студентами, які займалися за програмою загальної фізичної підготовки [6, с 113]. Найчастіше в цих групах застосовувалися елементи спортивних ігор, різновиди гімнастики, інших видів спорту. Перевагою такої форми організації занять $є$ високий емоційний фон і можливість врахування інтересів студентів.

Використання у студентів вправ силового спрямування дає можливість значно підвищити ефективність занять за умови дотримання принципу індивідуалізації, тобто врахування фізичних можливостей організму студента мотивації. Як стверджує П.М. Гунько [4,с 15], планування таких навантажень повинно здійснюватися з урахуванням виду і характеру силових вправ, об'єму та інтенсивності навантаження, кількості повторень 
і величини обтяження, частоти тренувальних занять і тривалості силової роботи, кількості та черговості виконання силових вправ, інтервалів відпочинку між вправами, тощо.

Силові навантаження впливають на деякі показники фізичної підготовленості, такі як сила, силова витривалість та швидкісна сила. Вказані якості проявляються лише в рухових діях, які використовуються в процесі тренувань, тобто особи, що проявляють велику силу у силових вправах не в змозі проявити іï у спортивних іграх, плаванні чи бігу. Застосування вправ силової спрямованості підвищує рівень інших рухових якостей: швидкості, гнучкості, координації. Зокрема, у студенток ЗВО в результаті занять силовими вправами спостерігалося зростання вибухової сили, швидкісно-силової витривалості, гнучкості.

\section{Література:}

1. Альошина А. Концептуальні основи профілактики i корекції функціональних порушень опорно-рухового апарату у дітей та молоді. Молодіжний науковий вісник Східноєвропейського національного університету імені Лесі Украӥнки. Фізичне виховання і спорт. 2015. № 18. C. 96-102.

2. Беликова Ж. А. Упражнения хатха-йоги как средство коррекции деформации позвоночника студентов специальных медицинских групп с нарушениями осанки: автореф. дисс. канд. пед.наук: 13.00.04 Белгород, 2012. 23c.

3. Голяка С.К., Маляренко І.В., Возний С.С.Корекція постави та контроль за іiі формуванням у процесі фізичного виховання. Методичні рекомендації для студентів факультету фізичного виховання та спорту. 2020. $-66 \mathrm{c}$.

4. Гунько, Петро Миколайович. Методика навчання студентів застосовувати силові навантаження в процесі фізичного виховання : автореф. дис. канд. пед. наук: 13.00.02. Київ, 2008. 20 с.

5. Дудко М.В. Характеристика состояния биогеометрического профиля осанки и физической подготовленности студентов в процессе физического воспитания. Физическое воспитание студентов. 2015. № 4. C. $30-35$

6. Куц-Бурдейна О. Вплив бігових навантажень у змішаному режимі енергозабезпечення на функцію зовнішнього дихання студентів, які мають порушення постави. Молодіжний науковий вісник Східноєвропейського національного університету імені Лесі Украӥнки. Фізичне виховання і спорт. 2016. № 23. C. 111-115. 
7. Мартынюк О. А. Коррекция нарушений пространственной организации тела студенток в процессе физического воспитания : автореф. дисс. канд. наук по физ. воспитанию и спорту : 24.00.02. Киев. 2011. 20 с.

DOI https://doi.org/10.30525/978-9934-26-182-4-37

\title{
МОРФОФУНКЦІОНАЛЬНІ ЗМІНИ НЕОКОРТЕКСУ ЩУРЯТ ПІСЛЯ АНТЕНАТАЛЬНОЇ СТИМУЛЯЦЇ
}

\author{
Зідрашко Г. А. \\ кандидат медичних наук, \\ доиент кафедри гістології, ичитології, ембріології \\ Запорізький державний медичний університет \\ Свтушенко В. М. \\ доктор медичних наук, професор \\ в/о завідувача кафедри гістології, иитології, ембріології \\ Запорізький державний медичний університет \\ Пащенко I. B. \\ кандидат медичних наук, \\ дочент кафедри пропедевтики дитячих хвороб \\ Запорізький державний медичний університет \\ м. Запоріжжя, Украӥна
}

Актуальність. В сучасний час нейротропні і психотропні речовини почали застосовувати в період вагітності у жінок, які страждають різними захворюваннями. Встановлено, що порушення функції внутрішніх органів або залоз внутрішньої секреції, а також наявність гестозу у вагітних призводить до хронічної гіпоксії і появи вроджених захворювань нервової системи плода. Встановлено, що не тільки грубі ушкодження, але навіть недорозвинення мозку під час ембріогенезу, після народження, як правило, не компенсується повністю. Тому виникає необхідність вирішення питання про можливу стимуляцію внутрішньоутробних процесів розвитку мозку, тобто лікування внутрішньоутробного плода в тих випадках, коли, внаслідок захворювання вагітної, пренатальний онтогенез протікає в умовах, відхилених від норми. 